\title{
Article/Artigo
}

\section{Observation of initial clinical manifestations and repercussions from the treatment of 314 human injuries caused by black sea urchins (Echinometra lucunter) on the Southeastern Brazilian coast}

\author{
Observação das manifestações clínicas iniciais e sua influência no tratamento de 314 \\ acidentes causados por ouriços-do-mar pretos (Echinometra lucunter) na região sudeste \\ do Brasil
}

Vidal Haddad Junior ${ }^{1}$

\begin{abstract}
Introduction: Injuries caused by sea urchins are the most common caused by marine animals in humans in Brazil, with the black sea urchin (Echinometra lucunter) causing the most injuries to bathers. Methods: This study observed 314 human wounds with emphasis on the early observation of clinical signs and symptoms and their implications on the recommended treatment. Results: All the injuries were caused by black sea urchins and were observed in bathers. The lesions and the pain were associated with penetration of the spines; there was no early inflammation or pain without pressure on the wounded places. Complications arising from this kind on injury, including infections and foreign body granulomas, are associated with the permanence of the spines in the wounds. Conclusions: The study confirmed that this kind of injury is the most common accident caused by aquatic animals in Brazil. The main therapeutical recommendation is early removal of the spines to prevent late complications, such as infections and the formation of foreign body granulomas.
\end{abstract}

Keywords: Dangerous aquatic animals. Black sea urchin. Echinometra lucunter. Brazil.

\section{RESUMO}

Introdução: Os acidentes causados por ouriços-do-mar são as ocorrências por animais marinhos mais comuns no país. O ouriço-do-mar preto (Echinometra lucunter) é a espécie que mais causa ferimentos em banhistas. Métodos: Este trabalho registrou e estudou 314 agravos com ênfase nas manifestações clínicas iniciais observadas e suas implicações na terapêutica recomendada. Resultados: Todos os acidentes foram causados pelo ouriço-domar preto e aconteceram em banhistas. As lesões e a dor foram associadas ao trauma causado pela penetração das espículas (não ocorreu inflamação ou dor imediata sem pressão sobre os pontos comprometidos). As complicações deste tipo de acidente, incluindo infecções e granulomas de corpo estranho, estão associadas com a permanência das espículas nos ferimentos. Conclusões: Foi confirmado o fato do acidente causado por esta espécie ser o mais comum no Brasil e apresentar caráter traumático, sendo a principal recomendação a retirada precoce dos espinhos para prevenção de complicações tardias como as infecções e formação de granulomas de corpo estranho.

Palavras-chaves: Animais aquáticos perigosos. Ouriço-do-mar preto. Echinometra lucunter. Brasil.

1. Faculdade de Medicina de Botucatu, Universidade Estadual Paulista, São Paulo, SP. Address to: Dr. Vidal Haddad Junior. Caixa Postal 557, Rubião Jr, 18603-970 Botucatu, SP, Brasil. Phone: 55 143882-4922

e-mail: haddadjr@fmb.unesp.br

Received in 31/05/2011

Accepted in 29/07/2011

\section{INTRODUCTION}

Human presence in aquatic ecosystems is on the rise for both commercial (fishing) and recreational purposes (sea bathing and aquatic sports), which leads to a large number of injuries from marine animals $s^{1-4}$. Knowledge about these injuries is important for the medical community.

Sea urchins are classified in the Phylum Echinodermata and the Class Echinoidea ${ }^{1,2,4}$. They are round, slow-moving, non-aggressive animals found in rocks and in tropical and temperate coral reefs. Spines made of calcium carbonate are attached to the tegument (Figure 1). These spines can carry toxins. The toxic substances so far identified include steroids, serotonin, glycosides, cholinergic substances, histamine, and bradykinin-like substances ${ }^{1-4}$. Some species have toxins in or on the surface of their spines, or in the pedicellaria, tubular organs with pincer-like jaws at their extremities. Pedicellariae do not cause envenomation at the time of the accident; prolonged contact with the victim is required ${ }^{1,5}$.

The species found along the Brazilian coast are similar to those found in the eastern Atlantic, but have some differences from animals in the Caribbean and the North America. The most common species in Brazil is the black sea urchin or pindaúna (Echinometra lucunter), commonly found along the whole Brazilian coast; it has the habit of living in colonies in areas commonly frequented by bathers (shallow waters) ${ }^{1-4}$. Accidents from black sea urchins make up almost all the injuries from sea urchins in Brazil, a fact that assumes great importance, as sea urchins are responsible for $50 \%$ of all accidents caused by marine animals in Brazil $^{1-3}$. Thus, studies on this species are important for professionals who provide care in emergency situations and for dermatologists in clinics, as there 


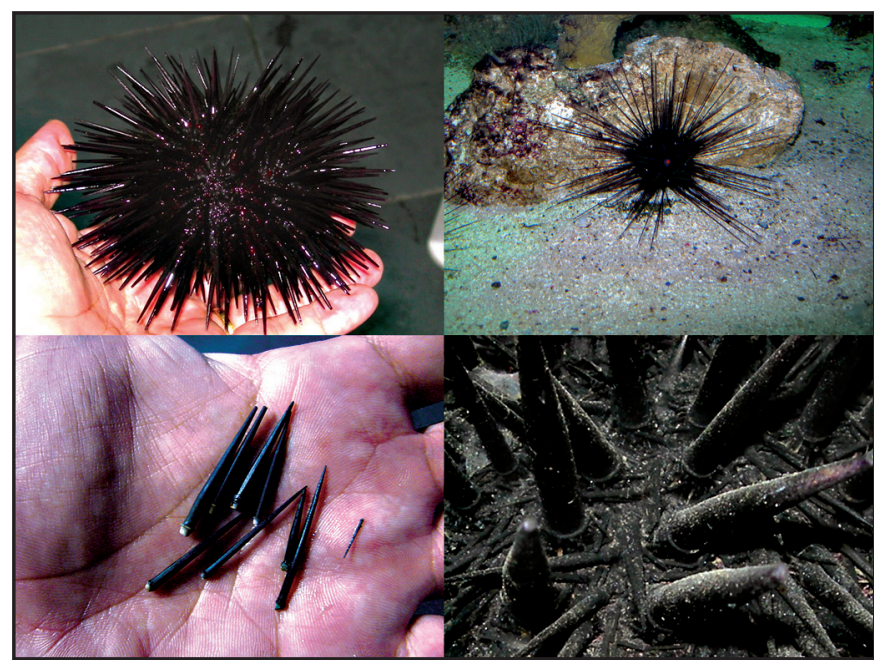

FIGURE 1 - Right: The black sea urchin (Echinometra lucunter), the species most associated with human injuries in Brazil. Left: A specimen of the highly venomous sea urchin of the Diadema genus. Below: Spines of the black sea urchin in detail Photographs: Vidal Haddad Junior.

are late complications that are difficult to resolve, such as bacterial and fungal infections and the formation of foreign body granulomas in sites where spine fragments remain.

Other sea urchin species inhabit our coast, but they are of minimal epidemiological significance ${ }^{1}$. The purple or green sea urchin (Lytechinus variegatus) is rarely associated with injuries. In some locations along the Brazilian coast specimens of the Diadema genus can be found; these can cause severe envenomation by the direct action of toxins found in their hollow spines ${ }^{1-3}$.

The primary injury caused by sea urchins is due to penetration of spines. The most commonly affected areas are the feet and ankles (mainly the plantar regions, when victims step on sea urchins) and the hands, for manipulation or as a defence mechanism when divers are dragged on to rocks by wave action ${ }^{1-4}$. Spine penetration causes pain, bleeding, and in later phases, erythema and oedema. When joints are penetrated, synovitis can occur.

Systemic symptoms are especially common when the toxin is injected in the wound from fifteen or more spines, but only in species capable of causing envenomation. These symptoms include paresthesia, radiated pain, hypotension, muscular weakness, dyspnea, aphony, deafness, and even death ${ }^{1-4}$. Envenomation is associated with early intense pain and inflammation ${ }^{1-5}$. In Brazil, nearly all injuries are traumatic, provoking moderate pain on local compression with slight or no local inflammation in the first few hours after envenoming ${ }^{1-4}$.

We can observe delayed complications such as granuloma formation ${ }^{6,7}$, chronic arthropathy, persistent neuropathy, local bone destruction, and vesicle formation ${ }^{8}$. The possible granulomatous reaction mechanism is due to foreign body reactions to various inorganic substances contained in the spines (calcium carbonate, magnesium carbonate, calcium sulphate, phosphates, and siliceous dioxide $)^{6,7}$. Lesions are pink to blue papules and consist of $2-5 \mathrm{~mm}$ nodules that later become brown. Oedema is a different process associated with plasma or water in the skin and can be observed in inflammatory diseases or after trauma. Hyperkeratosis is common ${ }^{7}$.

From an observation of 314 black sea urchin accidents in humans (predominantly in bathers), the author describes the evolution of the accidents, observing clinical signs and symptoms soon after spine penetration (up to $24 \mathrm{~h}$ ) and after $72 \mathrm{~h}$ to evaluate the effects of trauma and possible inflammatory agents inoculated by the spines. From these results first-aid measures and complementary late therapy can be established for injuries caused almost entirely by E. lucunter in Brazil.

\section{METHODS}

Patients were observed by the author at the time of the accident and 72h later in the Ubatuba Emergency Room (State of São Paulo, Brazil). Patients were invited to participate in the study and to sign an authorization form with information on the experiment, which was authorized by the Ethics Committee of the local Santa Casa and Maternity Hospital. Patients were observed and questioned for signs and symptoms (pain, bleeding, oedema and erythema, local purulent secretion, and nodules) and photographed for visual comparison at the two moments. The data were analysed for initial inflammatory phenomena and correlated with proposed measures for this type of injury in Brazil.

\section{RESULTS}

We observed 314 patients injured by sea urchins in the twoyear period 2009-2010. Injuries occurred at various beaches in the municipality. Nearly $65 \%$ of the victims were male and $82 \%$ were bathers. The plantar regions were compromised in $93 \%$ of cases. Extracted spines were collected and identified by the author as all belonging to the species E. lucunter, the black sea urchin.

Pain was the predominant symptom, present in all cases, but only perceived when patients placed plantar regions on the ground. Spontaneous intense pain was minimal (equivalent to less than $1 \%$ of accidents). Patients complained of pain when spines were removed, stating it to be more intense than spine penetration and retention pain at the time of the accident.

On examination, performed up to $6 \mathrm{~h}$ after the accident, there were no inflammatory phenomena at the spine penetration site (Figures 2 and 3). Further observations $72 \mathrm{~h}$ after onset revealed slight inflammation with discrete erythema surrounding the spine penetration areas (including points where spines had been extracted). Inflammation was more marked with associated oedema in about $5 \%$ of patients.

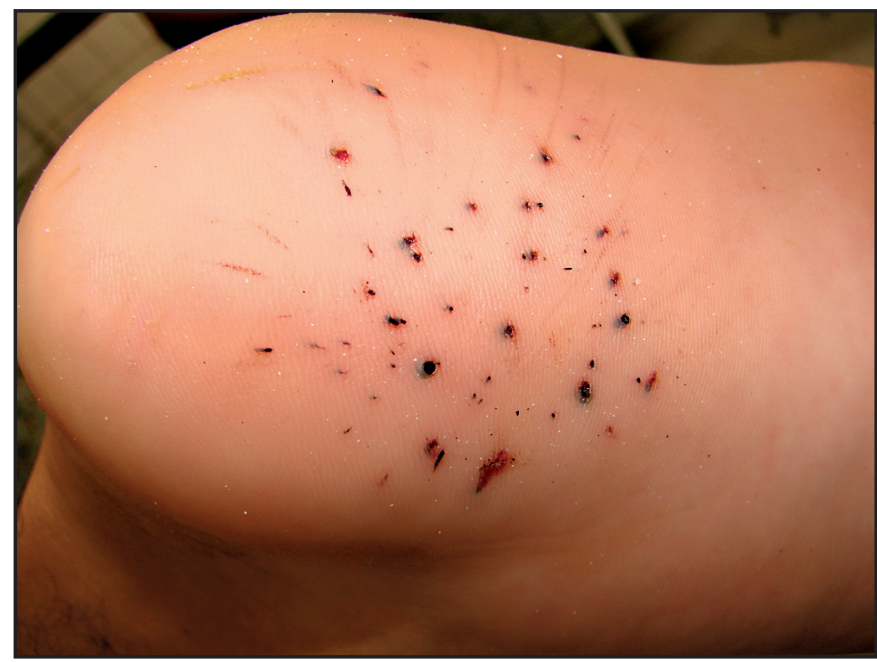

FIGURE 2 - Accident caused by a black sea urchin observed $3 \mathrm{~h}$ after a patient stepped on the animal. Note that there are no signs of inflammation at spine penetration point. The patient only presented pain when stepping on the wound site. Photograph: Vidal Haddad Junior. 


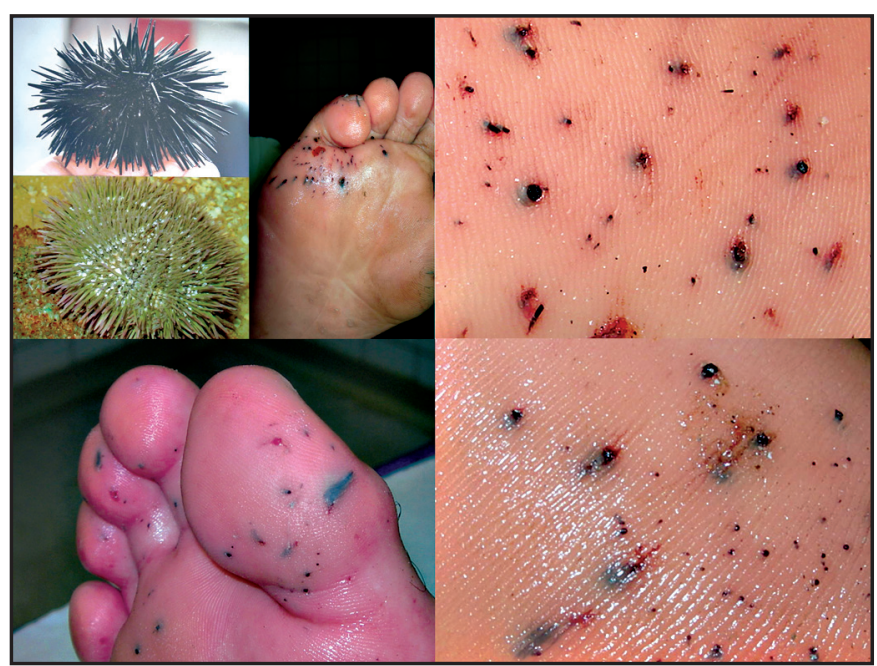

FIGURE 3 - The composite image shows a group of injuries caused by black sea urchins in the first few hours after spine penetration. It is clear that there are no present inflammatory alterations. Spontaneous pain was absent. Photographs: Vidal Haddad Junior.

\section{DISCUSSION}

The observation of 314 accidents caused by the black sea urchin E. lucunter has revealed interesting data about the phenomena triggered by spine penetration and the therapeutic measures recommended. The recent identification of experimental inflammatory effects triggered after penetration of extracts taken from the spines can be interpreted as a possible sign of toxins in the spines, although other proteins may trigger similar processes ${ }^{8}$. Apart from these findings, clinical observations demonstrate bleeding at spine entry points, but clearly no initial spontaneous inflammation or pain, while envenomation by sea urchins is associated with early severe pain and inflammation, as described in accidents by the Diadema genus. Although recent experimental studies are worthy of respect, it seems clear that the cases in this study did not present the severe inflammatory reactions or severe pain compatible with toxin actions. Additionally, the patients were calm and seldom complained of pain when they did not place the plantar regions on the ground. There was inflammation in some cases (always after 12-24h), but this was mild, hardly noticeable at the time of the accident (Figures 2 and 3), increasing with time, and proportional to the presence of calcium carbonate foreign body lesions (spine fragments).

It is clear that there are venomous species of sea urchins, and recent publications show that there are toxins in E. lucunter spines ${ }^{8}$.
Data from this study show, however, that these substances do not interfere with the patient's clinical manifestations, especially in initial envenoming phases. Thus, indication of steroidal or nonsteroidal antiinflammatory drugs is precipitous at the early stages and is doubtful at the late stages (granulomatous phase) of accidents; these drugs also cause side effects.

Current recommendations for injuries caused by black sea urchins are supported by the data from this study, which confirm predominantly traumatic aspects to the accidents. The main treatment is immediate removal of spines under local anaesthetic. The entry point should be lightly scarified with a large-calibre hypodermic needle, and the spines of larger diameter should be removed; the spines of very fine diameter are difficult to access but are spontaneously expelled after inflammatory processes triggered by their presence. Extraction is not easy but is necessary, because retained fragments can trigger infections and granulomatous nodules that can only be resolved by surgery. These guidelines are based on previous works showing a direct relationship between inflammation (including granulomas) and spines remaining in the $\operatorname{skin}^{1-7}$.

\section{CONFLICT OF INTEREST}

The authors declare that there is no conflict of interest.

\section{REFERENCES}

1. Haddad Jr V. Atlas de animais aquáticos perigosos do Brasil - guia médico de identificação e tratamento de acidentes. São Paulo: Editora Roca; 2000.

2. Haddad Jr V. Animais aquáticos potencialmente perigosos do Brasil: guia médico e biológico. São Paulo: Editora Roca; 2008.

3. Cardoso JLC, França FOS, Wen FH, Malaque CMS, Haddad Jr V. Animais peçonhentos no Brasil: biologia, clínica e terapêutica. $2^{\text {nd }}$ ed. São Paulo: Editora Sarvier; 2009.

4. Haddad Jr V. Animais aquáticos de importância médica. Rev Soc Bras Med Trop 2003; 36:591-597.

5. Hendler G, Miller JE, Pawson DL, Kier PM. Echinoderms of Florida and the Caribbean. Sea Stars, Sea Urchins, and Allies. Washington: Smithsonian Inst Press; 1995.

6. Haddad Jr V, Novaes SPMS, Miot HA, Zuccon A. Accidents caused by sea urchins - the efficacy of precocious removal of the spines in the prevention of complications. An Bras Dermatol 2002; 77: 123-128.

7. Rossetto AL, Mora JM, Haddad Jr V. Sea urchin granuloma. Rev Inst Med Trop São Paulo 2006; 48:303-306.

8. Sciani JM, Zychar BC, Gonçalves LRC, Nogueira TO, Giorgi R, Pimenta DC. Pro-inflammatory effects of the aqueous extract of Echinometra lucunter sea urchin spines. Exp Biol Med 2011; 236:277-280. 